San Jose State University

SJSU ScholarWorks

Faculty Publications, Urban and Regional

Planning

Urban and Regional Planning

January 2014

\title{
How effective are current household recycling policies? Results from a national survey of U.S. households
}

Hilary Nixon

San Jose State University, hilary.nixon@sjsu.edu

Jean-Daniel M. Saphores

University of California, Irvine

Follow this and additional works at: https://scholarworks.sjsu.edu/urban_plan_pub

Part of the Economics Commons, and the Engineering Commons

\section{Recommended Citation}

Hilary Nixon and Jean-Daniel M. Saphores. "How effective are current household recycling policies?

Results from a national survey of U.S. households" Resources Conservation and Recycling (2014): 1-10.

This Article is brought to you for free and open access by the Urban and Regional Planning at SJSU ScholarWorks. It has been accepted for inclusion in Faculty Publications, Urban and Regional Planning by an authorized administrator of SJSU ScholarWorks. For more information, please contact scholarworks@sjsu.edu. 


\title{
HOW EFFECTIVE ARE CURRENT HOUSEHOLD RECYCLING POLICIES? Results from a national survey of U.S. households
}

\author{
Jean-Daniel M. Saphores ${ }^{\mathrm{a}}$ and Hilary Nixon ${ }^{\mathrm{b}}$ \\ ${ }^{a}$ Corresponding Author, Professor, \\ Civil and Environmental Engineering, \\ Planning, Policy, \& Design, \& Economics Departments \\ University of California, Irvine, CA 92697 USA \\ Phone: 949-824-7334; saphores@uci.edu \\ ${ }^{\mathrm{b}}$ Associate Professor, Department of Urban and Regional Planning \\ San Jose State University, San Jose, CA 95192 USA \\ Phone: 408-924-5852; hilary.nixon@ sjsu.edu
}

\begin{abstract}
This paper analyzes a unique dataset collected during a 2006 national survey of U.S. households to explore the effectiveness of common household recycling policies for metals, glass, and plastics: curbside recycling, drop-off recycling, deposit-refund systems (bottle bills), and marginal pricing for household waste. After estimating either generalized ordered logit or multinomial logit models, we find that the most important determinants of household recycling are people's attitudes towards recycling. Our results also suggest that omitting internal variables (perceived recycling obstacles and benefits as well as moral considerations) may bias policy coefficients. Socio-economic variables are typically not statistically significant, with the exceptions of young adults and of African Americans who tend to recycle less than others. Policies with the largest odds ratios are curbside recycling (which is further strengthened if recycling is mandatory), followed by the presence of drop-off collection centers nearby. Bottle bills are also statistically significant but their odds ratios are smaller, possibly because refunds are relatively small and typically do not change for years. Finally, marginal pricing appears to have a limited impact on recycling. These results suggest avenues for improving household recycling at a time when recycling rates appear to be plateauing.
\end{abstract}

Keywords: household recycling; environmental attitudes; bottle bills; deposit-refund; marginal pricing. 


\section{Introduction}

Of the 250 million tons of municipal solid waste Americans generate annually, only approximately $35 \%$ is recycled (U.S. EPA, 2013). More than 50 million tons of metals, glass, and plastics are discarded annually, even though glass and many metals are in principle "infinitely recyclable" (Tonn et al., 2014; see Reck and Graedel, 2012 about limitations for metals recycling), and plastics can be recycled many times if different plastic types are melted separately and the use of additives is minimized. Quantifying the social benefits of recycling is difficult, however, because the avoided pollution and the reduced resource depletion are scattered over many heterogeneous jurisdictions (raw materials are often extracted in foreign countries), but it is well known that virgin material extraction is typically resource-intensive and has many adverse environmental impacts. In contrast, recycling metal, glass, and plastics nationwide saved an estimated 24.7 million metric tons (MMT) of $\mathrm{CO}_{2}$ equivalent in 2012, with 20.7 MMT coming from metals recycling alone (U.S. EPA, 2013).

After steady increases during the 1980s and the 1990s, overall recycling rates in the U.S. have leveled off over the past few years (see Figure 1). Although the recycling rate of some materials has increased substantially between 2000 and 2012 (e.g., it jumped from $23 \%$ to $28 \%$ for glass and from $6 \%$ to $9 \%$ for plastics), it has remained flat for others (for metals excluding aluminum), and it has decreased for aluminum (from a peak of $36 \%$ in the early 1990 s to $20 \%$ in 2012 ), probably because of the decline in the price of aluminum (Schlesinger, 2007). These trends show that much remains to be done to reach the elusive goal of zero waste, which has been adopted by a number of communities (e.g., see http://zwia.org/news/zero-waste-communities/). 
Several policies can be implemented to foster household recycling. A first option is to provide curbside recycling, which makes recycling a lot more convenient. Today, more than $70 \%$ of the U.S. population is served by a curbside recycling program, with coverage ranging from $60 \%$ in the West to almost universal access in the densely populated Northeast (U.S. EPA, 2014). Second, regulations (i.e., state-mandated recycling) can also help recycling. According to van Haaren, Themelis, and Goldstein (2010), state-level recycling rates vary from a low of $1 \%$ in Louisiana, where there is no state-level mandatory recycling regulation, to a high of $40 \%$ in California, where there is (Northeast Recycling Council, 2011). Currently, twenty states mandate recycling for at least one material, including eight states for aluminum, tin cans, and glass containers. A third option is to implement market-based policies such as unit pricing for household waste or deposit-refund programs for beverage containers. By the mid-2000s, over 7,000 jurisdictions across the country had implemented a municipal solid waste user fee system (Skumatz, 2008). Moreover, in 2006 eleven states had so-called "bottle bills" (see Table 1). Data from the Container Recycling Institute (Gitlitz, 2013) show that recycling rates for covered beverage containers are significantly higher in bottle bill states than in other states (see Figure 2).

In this context, our paper contributes to the recycling and policy literatures by analyzing a unique dataset from a 2006 survey of U.S. households to quantify the impact on household recycling rates of the main recycling policies (voluntary or mandatory curbside recycling, implementing drop-off recycling centers, marginal pricing for trash, and deposit refund systems via bottle bills) for four common materials (aluminum, glass, metals excluding aluminum, and plastics). Our work expands Jenkins et al. (2003), which 
was based on a 1992 survey of U.S. households from 20 metropolitan areas, by analyzing a richer dataset (our models include questions about attitudes toward recycling and moral considerations) and by accounting for a wider range of policies (Jenkins et al. (2003) did not consider bottle bills). A better understanding of the determinants of household recycling is essential to implement more effective recycling policies.

The next section gives a brief overview of some key papers to justify our modeling choices. Section 3 summarizes our data collection efforts and provides an overview of our data. In Section 4, we present our modeling strategy before discussing our results in Section 5. Section 6 summarizes our findings.

\section{Literature Review}

Research on the determinants of household recycling stems back at least to the 1970s (see, e.g. Reid et al., 1976, or McGuiness, Jones, \& Cole, 1977). Key predictors of recycling behavior fall into three main categories: (1) external variables, such as demographic and socioeconomic characteristics; (2) internal variables, including attitudes, beliefs, and norms; and (3) policy and programmatic characteristics such as cost and convenience. For the purposes of this research, we focus on a few key studies published in the past decade to inform our choice of explanatory variables.

\subsection{External Variables}

Among recycling studies, demographic and socioeconomic characteristics are the most common predictors considered. In a recent meta-analysis by Miafodzyeva and Brandt (2013), age, income and education level are the most common variables studied, followed 
by gender and dwelling type. Generally, younger and older adults tend to face more barriers to recycling although do Valle et al. (2004) argue that as recycling becomes a societal norm, age becomes less influential. Income is often found to correlate positively with recycling, although there are exceptions. In Miafodzyeva and Brandt's (2013) metaanalysis, 11 studies find a positive correlation between income and recycling, one reports the reverse, and 5 studies conclude that there is no significant correlation between the two. Findings for education levels vary, with some studies reporting a positive correlation (e.g. Barr, Gilg, and Ford, 2005) and others concluding that it does not matter statistically for recycling (e.g., see Meneses and Palacio, 2005; do Valle et al., 2004).

Household size may also impact recycling, especially for materials that require some processing (such as glass that needs to be washed before recycling) because of economies of scale (Jenkins et al., 2003). In addition, larger families may be more likely to buy in bulk, which could decrease the packaging per item purchased and the effort needed to achieve a given recycling rate.

Although some evidence suggests that women are more likely to engage in proenvironmental behavior (Hunter, Hatch, and Johnson, 2004), most household recycling studies find that gender is not statistically significant (Mizfodzyeva and Brandt, 2013), which is not surprising since recycling tends to be a household activity.

Moreover, empirical evidence suggests that residents of single-family structures recycle more than multi-family dwellers (e.g., see Ando and Gosselin, 2005), possibly because single family homes typically offer more storage space for recyclables than apartments or condominiums. Nixon and Saphores (2009) also note that ownership status (i.e., owning versus renting) may affect recycling behavior. 


\subsection{Internal Variables}

The second category of variables includes socio-psychological factors such as environmental attitudes and moral beliefs, as well as environmental knowledge and information. Although published studies rely on a variety of measures, results overwhelmingly point to a positive correlation between environmental concerns - seen as "motivational factors" - and recycling behavior. For example, in Miafodzyeva and Brandt's (2013) meta-analysis, 25 studies report a positive relationship between moral norms and recycling, and only 5 identify no significant relationship. In their analysis of willingness to recycle e-waste, Saphores, Ogunseitan, and Shapiro (2012) find that moral beliefs is the most important statistically significant variable in their model.

A number of empirical studies conclude that public education and information campaigns are effective approaches to promote recycling (e.g., see Barr, 2007; or Siddique, Lupi, and Joshi, 2010), but few papers are explicit about how to use media to foster recycling. One exception is Nixon and Saphores (2009) who report that face-toface communication is the most effective single medium, although relying on multiple media to inform households about recycling is best. Apart from providing information about what to recycle and where, public education campaigns that focus on the negative impacts from dumping trash tend to stimulate recycling (e.g., see Saphores et al. (2012) on how awareness of toxic materials in e-waste helps predict willingness to recycle).

\subsection{Policy Variables and Programmatic Characteristics}

Program characteristics comprise the final major category of factors influencing recycling behavior. Variables falling into this category include program design (e.g., curbside 
versus drop-off, pick-up frequency, container size and style), whether recycling is mandatory, as well as economic features such as unit pricing or deposit-refunds for specific materials. Among these, program convenience is consistently a major determinant of recycling behavior (Miafodzyeva and Brandt. 2013).

Several papers have examined the impact of making recycling mandatory. For example, in their study of households across Ontario, Canada, Ferrara and Missios (2005) find that mandatory recycling programs and user fees on trash collection significantly increases recycling for a wide range of common household materials. Yang and Innes (2007) reach the same conclusion for common household materials in Taiwan. In their nationwide study of plastic water bottle recycling in the U.S., Viscusi et al. (2013) report that households who live in states with effective recycling laws - including mandatory recycling - are more likely to recycle plastic water bottles.

Economists have long advocated market-based instruments to boost recycling, including unit pricing for trash (e.g., see Hong, 1999; Jenkins et al., 2003) and depositrefund programs for recyclables (e.g., see Walls, 2003; Stavins, 2001; or Calcott and Walls, 2005). Oregon and Vermont passed the first beverage container deposit laws in the early 1970s, which require consumers to pay a refundable deposit on some types of beverage containers and manufacturers to take these back for recycling (Gitlitz, 2013). Container recycling rates at the time were very low, ranging from $1.3 \%$ for beer cans (steel or glass) to $10 \%$ for aluminum containers (U.S. EPA, 2014). In another recent study, Viscusi et al. (2013) conclude that households who reside in states with both effective recycling laws and a deposit-refund program recycle on average 8.6 out of every 10 plastic water bottles, an increase of 4.3 bottles compared to households in other states. 
However, they also find that policy interventions such as deposit-refund programs can have a discontinuous effect with a greater impact on non-recyclers, lower income households, and self-described non-environmentalists.

A common concern in the literature is the risk for deposit-refund programs to discourage municipalities from establishing curbside recycling programs by sharply reducing the curbside collection of profitable materials (such as aluminum). This effect is illustrated in Kinnaman and Fullerton's (2000) model of household demand for recycling, although Kinnaman (2005) finds that it is not statistically significant. Moreover, Bolaane's (2006) study of recycling behavior in Gaborone finds a strong correlation between people's awareness of a deposit-refund program and whether they recycle.

\subsection{Summary}

Our review of selected recycling papers indicates that recycling behavior is the result of a diverse set of factors; convenience, social norms, and moral considerations lead the way in terms of importance, followed by environmental awareness, program knowledge, and environmental concerns. Demographic variables typically play a smaller role than internal variables, although the latter were often unavailable in previous studies. In our models, in addition to common demographic variables (age, income, ethnicity, education, household size, and dwelling type), we therefore include a rich set of socio-psychological variables that reflect personal responsibility, norms, and environmental concerns, as well as attitudes towards recycling. Finally, our policy and programmatic variables reflect the presence of bottle bill regulations, curbside recycling availability, marginal pricing for household trash, and distance to the nearest drop-off recycling collection center. 


\section{Data}

Our dataset was collected through an Internet-based survey of a random subset of Knowledge Networks' (KN) 43,000-member online research panel, which was built to be representative of the U.S. population using probability sampling techniques. KN provides Internet access and hardware to panel members who need it, and rewards survey completion with incentive points redeemable for cash. To remain active, members of KN's panel must complete at least one out of every six surveys they are assigned, but they are never asked to answer more than four surveys per month. For all panel members, $\mathrm{KN}$ collects detailed demographic data, which are updated annually and are available to researchers using KN's services. Panel members are notified about assigned surveys via email or mail, with follow-up reminders as needed. For more information about KN's panel, see www.knowledgenetworks.com/knpanel/index.html.

A pilot study of our survey was conducted with 110 panel members (with a 66\% response rate) in February 2006. After incorporating feedback, the survey was fielded from late March through early April 2006. A total of 3,048 panel members were contacted and 2,136 participated in our survey resulting in a 70.1\% response rate, which is similar to other $\mathrm{KN}$ surveys.

Our survey comprised four parts. In part one, we asked general questions about environmental attitudes and volunteering. Part two focused on household waste management; it included questions about the recycling of common household materials, characteristics of available waste management programs, attitudes towards recycling, and sources of information about recycling. Part three dealt with electronic waste recycling 
and part four asked a few additional demographic questions to supplement information provided directly from $\mathrm{KN}$.

Of our 2,136 respondents, 1,089 (51.0\%) were served by curbside recycling, which was mandatory for 305 of them (14.3\% of the total); $526(24.6 \%)$ were within 5 miles of a drop-off recycling center for at least one of the four materials considered in this study; $540(25.3 \%)$ lived in states with bottle bills; and 177 (8.3\%) were subjected to marginal pricing for household trash, but only 18 respondents knew the corresponding marginal price so our models simply include a binary variable indicating the presence of marginal pricing for household trash.

A comparison of socioeconomic characteristics of our respondents with those of the U.S. population based on Census data (Supplementary Table 1) shows a reasonably good match with the U.S. population, although our respondents are somewhat less ethnically and racially diverse and moderately less wealthy. In addition, our respondents are slightly older and less likely to have a bachelor's degree. These differences are somewhat minor, however, so we are confident that our results can provide insights into the effectiveness of current recycling policies for U.S. residents.

\section{Methodology}

\subsection{Factor Analysis}

We first performed a factor analysis (Thompson, 2004) of the nine survey questions dealing with obstacles to recycling and with potential benefits of recycling (see Supplementary Table 2). Questions were split in two groups to capture separately perceived obstacles to recycling and perceived social benefits of recycling. The resulting 
factors were then used as explanatory variables in our recycling models.

\subsection{Modeling Recycling}

After inquiring if our respondents recycle, our survey asked those who do to indicate how much aluminum, glass, metals other than aluminum, and plastics they recycle. Each of these four questions originally had five categories $(<10 \%, 11$ to $35 \%, 36$ to $65 \%, 66$ to $90 \%$ and over $90 \%$ ), but we reorganized them into the following four categories to better balance the number of respondents in each category: 1) "Does not recycle"; 2) "Recycles between 1 and 35\%"; 3) "Recycles 36 to 90\%"; and 4) "Recycles over 90\%". Figure 3 shows a summary of answers for each material. Supplementary Table 3 presents summary statistics for all variables included in our models.

To explain our respondents' recycling behavior, we started from standard ordered response models like the ordered logit or ordered probit (Long and Freese, 2006). One implication of these ordered response models is the "parallel lines" property, which implies that probability curves (i.e., curves that give $\operatorname{Pr}\left(y_{i}>q\right)$ for $\left.q \in\{1,2,3\}\right)$ are parallel. The validity of this assumption can be examined by estimating binary models for all but one values of $q$ and testing that the resulting slopes are equal. If the parallel lines assumption is not verified, another model is needed.

One possibility is the generalized ordered model, which allows model coefficients to differ between recycling category. It can be written (Williams, 2006):

$$
\operatorname{Pr}\left(y_{i}=q\right)=\left\{\begin{array}{l}
1-F\left(\tau_{q}+\mathbf{X}_{i} \boldsymbol{\beta}_{q}\right), \text { if } q=1, \\
F\left(\tau_{q-1}+\mathbf{X}_{i} \boldsymbol{\beta}_{q-1}\right)-F\left(\tau_{q}+\mathbf{X}_{i} \boldsymbol{\beta}_{q}\right), \text { if } q=2 \text { or } 3, \\
F\left(\tau_{q-1}+\mathbf{X}_{i} \boldsymbol{\beta}_{q-1}\right), \text { if } q=4,
\end{array}\right.
$$

where $q$ is one of the four recycling categories defined above; $F$ is a cumulative 
distribution function (cdf); $\mathbf{X}_{i}$ is a $1 \times k$ vector of explanatory variables; and $\boldsymbol{\beta}_{\mathbf{1}}, \boldsymbol{\beta}_{\mathbf{2}}$, and $\boldsymbol{\beta}_{\mathbf{3}}$ are $\mathrm{k} \times 1$ vectors of unknown coefficients to be estimated jointly with unknown "cutpoint" coefficients $\tau_{1}, \tau_{2}$; and $\tau_{3}$. Stata (the statistical package we used for our analyses) performs Wald tests (Greene 2011) to keep equal coefficients of variables that do not differ statistically across equations.

Following Williams (2006), we considered different distributions for $F$ but when AIC and BIC (Greene, 2011) differed by less than 3 between models, we selected logit link functions because the resulting models are easier to interpret. In that case, the odds that $\mathrm{y}>q$ versus $\mathrm{y} \leq q$ for $q \in\{1,2,3\}$ is given by

$$
\Omega_{>q \mid \leq q}\left(\mathbf{X}_{i}\right)=\frac{\operatorname{Pr}\left(y_{i}>q \mid \mathbf{X}_{i}\right)}{\operatorname{Pr}\left(y_{i} \leq q \mid \mathbf{X}_{i}\right)}=\exp \left(\tau_{q}+\mathbf{X}_{i} \boldsymbol{\beta}_{q}\right) .
$$

If $\Omega_{>q \mid \leq q}\left(\mathbf{X}_{i}, x_{m}+\delta\right)$ denotes the odds that $\mathrm{y}>q$ versus $\mathrm{y} \leq q$ obtained by adding $\delta>0$ to $x_{m}(m \in\{1, \ldots, k\})$ in Equation (2), the odds ratio of observing respondent " $i$ " in a recycling category $>q \in\{1,2,3\}$ versus a recycling category $\leq q$ for variable $x_{m}$ is

$$
\frac{\Omega_{>q \mid \leq q}\left(\mathbf{X}_{i}, x_{m}+\delta\right)}{\Omega_{>q \mid \leq q}\left(\mathbf{X}_{i}\right)}=\exp \left(\delta \beta_{q, m}\right) .
$$

Equation (3) implies that increasing $x_{j}$ augments the likelihood that a respondent will recycle more than she does now if and only if $\beta_{q, m}>0$; we thus report odds ratios $\exp \left(\beta_{q, m}\right)$, for $1 \leq m \leq k$, and denote each of these odds ratios by $\mathrm{OR}_{>q \mid \leq q}$ (we omit subscript " $m$ " for simplicity).

A second alternative (when the parallel lines property is not verified) is to estimate a multinomial logit model. In that case, the probability that respondent $i$ recycles in category $q \in\{2,3,4\}$ compared to category 1 (no recycling) is (Long and Freese, 2006): 


$$
\operatorname{Pr}\left(y_{i}=q \mid \mathbf{X}_{i}\right)=\frac{\exp \left(\beta_{q, 0 \mid 1}+\mathbf{X}_{i} \boldsymbol{\beta}_{q \mid 1}\right)}{1+\sum_{j \in\{2,3,4\}} \exp \left(\beta_{j, 0 \mid 1}+\mathbf{X}_{i} \boldsymbol{\beta}_{j \mid 1}\right)},
$$

where the three $k \times 1$ coefficient vectors $\boldsymbol{\beta}_{j \mid 1}$ and the three $\beta_{j, 0 \mid 1}$ scalar coefficients are estimated via maximum likelihood. Thus, the odds that respondent " $i$ " recycles in category $q \in\{2,3,4\}$ compared to category 1 (no recycling) are

$$
\Omega_{q \mid 1}\left(\mathbf{X}_{i}\right)=\frac{\operatorname{Pr}\left(y_{i}=q \mid \mathbf{X}_{i}\right)}{\operatorname{Pr}\left(y_{i}=1 \mid \mathbf{X}_{i}\right)}=\exp \left(\beta_{q, 0 \mid 1}+\mathbf{X}_{i} \boldsymbol{\beta}_{q \mid 1}\right) .
$$

If $\Omega_{q \mid 1}\left(\mathbf{X}_{\mathbf{i}}, x_{m}+\delta\right)$ denotes the odds obtained by adding $\delta>0$ to explanatory variable $x_{m}$ $(m \in\{1, \ldots, k\})$ in (5), the odds ratio of recycling in category $q \in\{2,3,4\}$ relative to not recycling $(q=1)$ is then

$$
\frac{\Omega_{q \mid 1}\left(\mathbf{X}_{i}, x_{m}+\delta\right)}{\Omega_{q \mid 1}\left(\mathbf{X}_{i}\right)}=\exp \left(\delta \beta_{q, m \mid 1}\right)
$$

Hence, a unit increase in $x_{m}$ increases the likelihood of recycling in category $q$ relative to not recycling if and only if $\beta_{q, m \mid 1}>0$. We thus report odds ratios $\exp \left(\beta_{q, m \mid 1}\right)$ (for $1 \leq m \leq k$ ), and we denoted them by $\mathrm{OR}_{q \mid 1}$ (we omit subscript " $m$ " for simplicity).

One implication of Equation (5) is that the odds of any pair of recycling categories do not depend on the characteristics of other recycling categories. To assess this property (the independence of irrelevant alternatives, IIA), we relied on the suest-based Hausman test in Stata instead of the original Hausman test or the Small-Hsiao test (Greene, 2011). Indeed, the former often yields different results depending on the base category, and results of the latter depend on the way the sample is partitioned (Long and Freese, 2006). 


\section{Results}

All results were obtained using Stata 11.

\subsection{Factor analysis}

Based on the Kaiser criterion (Thompson, 2004), our analysis of the five questions dealing with potential obstacles to recycling and of the four questions assessing benefits of recycling gave two factors. They were normalized to be between 0 and 1 to facilitate their interpretation, where 1 indicates that a respondent does not view common obstacles to recycling as substantial (obstacles to recycling) or believes that recycling is beneficial to the environment and to the economy (benefits of recycling). More specifically, agreeing with items $4,6,7$, and 9 , and disagreeing with items $1,2,3,5$, and 8 (see Supplementary Table 2) indicates pro-recycling beliefs and brings both factors close to 1 . Supplementary Table 2 summarizes our analysis and shows that both factors pass common specification tests (see Thompson, 2004).

\subsection{Recycling Models}

None of the ordered logit models for the four household materials considered passed tests of the "parallel lines" property so we explored multinomial and generalized ordered logit models. Based on common specification tests, our preferred models are multinomial logits for aluminum and plastics (for both, we failed to reject the IIA using the suestbased Hausman test at 10\%), and generalized ordered logits for glass and for metals excluding aluminum. Multicollinearity is not present here because the largest variance inflation factor for the datasets of all four models considered is less than 2.3 (it is 
typically investigated for values above 5). Moreover, significance was assessed using robust standard errors. Odds ratios for all four preferred models are displayed in Tables 2 and 3; to lighten our notation, we do not indicate below the categories of odds ratios for the generalized ordered logit if they are equal for all recycling categories considered.

\subsubsection{External variables}

As expected from our review of the literature, common socio-economic characteristics are not statistically significant for explaining recycling behavior, with a handful of exceptions. First, compared to adults aged 45 to 59, younger adults (aged 18 to 29) are less likely to recycle common household materials $\left(\mathrm{OR}_{\mathrm{H} \mid \mathrm{N}}\right.$ equals $0.47 * * *$ for aluminum and $0.58 * *$ for plastics; $\mathrm{OR}>_{\mathrm{M} \mid \leq \mathrm{M}}$ equals $0.66 * *$ for other metals and $0.60 * *$ for glass). On the other hand, the presence of an adult over 65 in the household slightly boosts recycling, especially for "other metals" $\left(\mathrm{OR}=1.46^{* *}\right)$ and to a lesser extent for aluminum $\left(\mathrm{OR}_{\mathrm{H} \mid \mathrm{N}}\right.$ is $\left.1.41^{*}\right)$, compared to adults between 45 and 59.

Except for glass $\left(\mathrm{OR}=1.23^{* *}\right)$, the gender of the respondents has no impact on recycling, which is not surprising because this is a household activity. Likewise, ethnicity is typically not important, with the exception of African Americans who are less likely to recycle aluminum $\left(\mathrm{OR}_{\mathrm{M} \mid \mathrm{N}}=0.54 * *\right.$ and $\left.\mathrm{OR}_{\mathrm{H} \mid \mathrm{N}}=0.41^{* * *}\right)$, plastics $\left(\mathrm{OR}_{\mathrm{M} \mid \mathrm{N}}=0.62 *\right.$ and $\left.\mathrm{OR}_{\mathrm{H} \mid \mathrm{N}}=0.43 * * *\right)$, other metals $(\mathrm{OR}=0.48 * * *)$, and glass $(\mathrm{OR}=0.39 * * *)$. Educational attainment also typically does not matter statistically, and neither does income, although we note that dual income households have lower odds to be low recyclers for plastics $\left(\mathrm{OR}_{\mathrm{L} \mid \mathrm{N}}=0.56^{* *}\right)$ but higher odds to recycle other metals $(\mathrm{OR}=1.38 * * *)$.

Living in a single family house does not have a significant impact on recycling 
with the exception of aluminum $\left(\mathrm{OR}_{\mathrm{H} \mid \mathrm{N}}=1.46^{* *}\right)$. On the other hand, rural residents are more likely to be high recyclers for all 4 materials considered $\left(\mathrm{OR}_{\mathrm{H} \mid \mathrm{N}}=1.46^{* *}\right.$ for aluminum and plastics; $\mathrm{OR}_{>\mathrm{M} \mid \leq \mathrm{M}}=2.08^{* * *}$ for other metals; and $\mathrm{OR}>\mathrm{M} \mid \leq \mathrm{M}=1.60 * * *$ for glass); this may reflect that since rural residents often do not enjoy the convenience of curbside recycling and need to bring their own trash (recycling) to a dump (recycling center), so if they decide to recycle, they do so fully.

\subsubsection{Internal variables}

At the outset of this study, we hypothesized that attitudes, beliefs, and norms would play an important role in explaining recycling behavior, and this was confirmed by the magnitude and high levels of significance of the recycling factors and of the moral belief variable. The factor that reflects perceived obstacles to recycling is especially important for the high recycling group $\left(\mathrm{OR}_{\mathrm{H} \mid \mathrm{N}}=128.32 * * *\right.$ for aluminum, $\mathrm{OR}_{\mathrm{H} \mid \mathrm{N}}=231.34 * * *$ for plastics, $\mathrm{OR}_{>\mathrm{M} \mid \leq \mathrm{M}}=38.70 * * *$ for other metals, and $\mathrm{OR}=39.07 * * *$ for glass); the factor that captures perceived benefits of recycling is also important but not quite as influential $\left(\mathrm{OR}_{\mathrm{H} \mid \mathrm{N}}=7.90 * * *\right.$ for aluminum, $\mathrm{OR}_{\mathrm{H} \mid \mathrm{N}}=11.20 * * *$ for plastics, $\mathrm{OR}_{>\mathrm{N} \mid \leq \mathrm{N}}=5.75^{* * *}$ for other metals, and $\mathrm{OR}=3.69 * * *$ for glass). Although the coefficient of the moral obligation variable is statistically significant, its odds ratios are a lot smaller than those for the perceived obstacles to recycling factor (they are all under 5). The other two internal variables considered are only anecdotally significant and the magnitude of their odds ratios is smaller. 


\subsubsection{Policy variables}

Odds ratios are largest and highly significant for the binary variable indicating availability of curbside recycling; they range from $\mathrm{OR}=4.96^{* * *}$ for other metals to $\mathrm{OR}_{\mathrm{H} \mid \mathrm{N}}=19.39^{* * *}$ for plastics. Making curbside recycling mandatory further contributes to stimulating recycling for all recycling levels, although odds ratios for this measure are largest for the lowest recycling category (between $1 \%$ and 35\%).

Another way to make recycling convenient (apart from providing curbside pickup) is to operate of a drop-off collection recycling center within 5 miles of each dwelling. The coefficient of the corresponding variable in our models is almost always statistically significant and its odds ratio is largest for plastics $\left(\mathrm{OR}_{\mathrm{H} \mid \mathrm{N}}=6.31 * * *\right)$.

The variable indicating the presence of a state bottle bill is statistically significant for all materials considered but its odds ratios are smaller than for curbside recycling and in almost all cases than for the distance to the nearest drop-off recycling center, which indicates that current bottle bills have a smaller impact on recycling than curbside recycling and than providing convenient drop-off centers. Finally, marginal pricing for household waste (which was relatively rare among our respondents), is not statistically significant except for other metals $\left(\mathrm{OR}=1.55^{* *}\right)$ and for plastics $\left(\mathrm{OR}_{\mathrm{H} \mid \mathrm{N}}=1.65^{*}\right)$, which suggests that marginal pricing is currently too low to be effective.

\subsection{Importance of Internal Variables}

Since many recycling studies do not include internal variables, it is of interest to estimate our models again without internal variables. Results are presented in Tables 4 and 5.

First, we see that omitting internal variables only has a minor impact on the 
coefficients of external variables. One notable change compared to our full models is the statistical significance of income $\left(\mathrm{OR}_{\mathrm{H} \mid \mathrm{N}}=1.24 * *\right.$ for aluminum, $\mathrm{OR}_{\mathrm{H} \mid \mathrm{N}}=1.28 * *$ for plastics, $\mathrm{OR}=1.15^{* *}$ for other metals, and $\mathrm{OR}=1.25^{* *}$ for glass $)$.

Second, omitting internal variables substantially impacts coefficients of policy variables. On one hand, it inflates the importance of curbside recycling $\left(\mathrm{OR}_{\mathrm{H} \mid \mathrm{N}}\right.$ for aluminum jumps from $6.61^{* * *}$ in Table 2 to $10.36^{* * *}$ in Table 4 , and OR for glass almost doubles from $6.44^{* *}$ to $12.42^{* *}$, for example), and to a lower extent whether curbside recycling is mandatory or not $\left(\mathrm{OR}_{>\mathrm{N} \mid \leq \mathrm{N}}\right.$ for glass increases from $2.93 * * *$ to $3.80^{* * *}$, for example). Moreover, it overstates the importance of proximity to drop-off recycling centers, especially for glass recycling (in that case, $\mathrm{OR}_{>\mathrm{M} \mid \leq \mathrm{M}}$ almost doubles from $2.70 * * *$ with internal variables to $5.32 * * *$ without). On the other hand, omitting internal variables downplays the impact of state bottle bills for aluminum $\left(\mathrm{OR}_{\mathrm{H} \mid \mathrm{N}}=2.04 * * *\right.$

in Table 2 versus $1.79 * * *$ in Table 4$)$, glass $(\mathrm{OR}=1.94 * * *$ in Table 3 versus $1.71 * * *$ in Table 5), and especially plastics $\left(\mathrm{OR}_{\mathrm{H} \mid \mathrm{N}}=3.07 * * *\right.$ in Table 2 versus $2.29 * * *$ in Table 4$)$. In summary, our results suggest that omitting internal variables from models that explain recycling behavior may bias policy coefficients.

\section{Conclusions}

In this paper, we analyzed a national survey of U.S. households using discrete choice models to explore the effectiveness of various recycling policies, and more generally to understand the determinants of household recycling for four common materials: aluminum, other metals, glass, and plastics. 
Our results show that few socio-economic variables are statistically significant, although the recycling rates of younger adults (between 18 and 29) and AfricanAmericans are lower than for other adults. Education, gender, and income are statistically non-significant, while rural residents are likely to recycle more than their urban and suburban counterparts. These findings are in line with much of the published literature. As noted in Miafodzyeva and Brandt's (2013) meta-analysis, these variables tend to be weak predictors of recycling behavior. Our findings on rural residents contrast some of the earlier research that suggests city dwellers are more likely to recycle (Derksen \& Gartrell, 1993), but are similar to more recent work (Saphores et al., 2006).

Conversely, we find that internal variables tend to be very important determinants of household recycling. In particular, the factor summarizing perceived obstacles to recycling and to a lesser degree the factor capturing perceived benefits of recycling have large odds ratios and are highly significant for all four materials considered, which highlights the need to regularly educate the public about the benefits of recycling. According to Corral-Verdugo (1997), Nixon and Saphores (2009), and others, there is a direct link between knowledge related to recycling and recycling programs and behavior. Likewise, although not to the same extent, moral considerations play an important role in U.S. households' decision to recycle. As seen in Miafodzyeva and Brandt (2013), moral norms are almost always significant predictors of recycling behavior.

Overall, the most effective (based on odds ratios and significance) policy to foster recycling is to make recycling more convenient, either by providing curbside recycling services (the preferred approach) or by locating drop-off recycling centers close enough to people's residences. This was expected since the recycling literature consistently 
shows that convenience is a key determinant of recycling behavior (Miafodzyeva and Brandt's (2013) meta-analysis identified convenience as the "strongest predictor of recycling tendency"; see page 235). Moreover, making curbside recycling mandatory further increases its effectiveness (confirming, for example, Everett and Peirce, 1993).

By comparison, deposit-refunds for recyclables (via bottle bills) or marginal pricing for household waste are not very effective. For marginal pricing, this finding is in line with Jenkins et al. (2003). Asking people to pay to dispose of their trash may promote illegal dumping, so municipalities may be reluctant to embrace it. Depositrefunds do not have this drawback, however, but their current implementations suffer from relatively narrow scopes, a relatively low refund per container, and opposition from some beverage manufacturers who may be concerned by the complexity of statedependent regulations, not only in terms of refunds, but also with regard to the materials and beverages covered. Given that the overall recycling rate has plateaued in the United States in recent years, deposit-refund systems should be given another look to boost recycling, especially for larger items such as appliances and obsolete electronic products (e.g., see Saphores et al., 2012).

Finally, our results illustrate that omitting internal variables may lead to biased policy coefficients.

\section{Acknowledgements}

This research was supported in part by grants from the National Science Foundation (DMI-0223894 and CMS-0524903); the University of California Toxic Substances and Teaching Program award TS-30856; the AT\&T Foundation Industrial Ecology Faculty 
Fellowship; and the UC Research Discovery Program; their support is gratefully acknowledged. Useful comments from the editor-in-chief (Eric Masanet) and two anonymous referees are gratefully acknowledged. As usual, we are responsible for all remaining errors.

\section{References}

Barr, S., A. Gilg, and N. Ford. 2005. "Defining the Multi-Dimensional Aspects of Household Waste Management: a Study of Reported Behavior in Devon." Resources, Conservation and Recycling 45 (2): 172-92. http://dx.doi.org/10.1016/j.resconrec.2004.12.007.

Calcott, P, and Margaret Walls. 2005. "Waste, Recycling, and 'Design for Environment': Roles for Markets and Policy Instruments." Resource and Energy Economics 27 (4): 287-305. http://dx.doi.org/10.1016/j.reseneeco.2005.02.001.

California Department of Resources Recycling and Recovery. 2014. Beverages Subject to California Refund Value. Accessed 4/2/14 from http://www.calrecycle.ca.gov/Publications/Detail.aspx?PublicationID=1475.

Container Recycling Institute. 2013. Bottle Bills in the USA. Accessed 3/9/14 from: http://www.bottlebill.org/legislation/usa.htm.

Corral-Verdugo, V. 1997. "Dual 'Realities' of Conservation Behavior: Self-reports vs. Observations of Re-use and Recycling Behavior." Journal of Environmental Psychology 17 (2): 135-145.

Derksen, Linda, and John Gartrell. 1993. "The Social Context of Recycling." American Sociological Review 58 (3): 434-442.

Do Valle, Patrícia O., Elizabeth Reis, João Menezes, and Efigénio Rebelo. 2004. "Behavioral Determinants of Household Recycling Participation: the Portuguese Case." Environment and Behavior 36 (4): 505-40. DOI: $10.1177 / 0013916503260892$.

Gitlitz, Jenny. 2013. Bottled Up: Beverage Container Recycling Stagnates (2000-2010), U.S. Container Recycling Rates \& Trends, 2013. Container Recycling Institute, Culver City, CA.

Everett, Jess W., and J. Jeffrey Peirce. 1993. "Curbside Recycling in the U.S.A.: Convenience and Mandatory Participation." Waste Management \& Research 11 (1): 49-61.

Ferrara, Ida, and Paul Missios. 2005. "Recycling and Waste Diversion Effectiveness: Evidence From Canada." Environmental and Resource Economics 30 (2): 22138.

Graedel, T E, Julian Allwood, Jean-Pierre Birat, Matthias Buchert, Christian Hagelüken, Barbara K Reck, Scott F Sibley, and Guido Sonnemann. 2011. "What Do We Know About Metal Recycling Rates?" Journal of Industrial Ecology 15 (3): 35566. DOI: 10.1111/j.1530-9290.2011.00342.x.

Greene, William H., 2011. Econometric Analysis, $7^{\text {th }}$ edition, Prentice Hall. 
Hong, Seonghoon, 1999. "The effects of unit pricing system upon household solid waste management: The Korean experience" Journal of Environmental Management 57 (1): $1-10$.

Hunter, Lori M., Alison Hatch, and Aaron Johnson. 2004. "Cross-national Gender Variation in Environmental Behaviors." Social Science Quarterly 85(3): 677-694.

Kinnaman, T.C. and D. Fullerton. 2000. "Garbage and Recycling with Endogenous Local Policy." Journal of Urban Economics 48: 419-442. DOI: 10.1111/j.00384941.2004.00239.x.

Long, J.S., Freese, J. (2006) Regression Models for Categorical Dependent Variables Using Stata (2nd Edition). College Station: Stata Press.

McCarthy, J.E., 1993. Bottle Bills and Curbside Recycling: Are They Compatible? Congressional Research Service Report 93-114 ENR.

McGuinness, J., A. P. Jones, and S. G. Cole. 1977. "Attitudinal Correlates of Recycling Behavior.” Journal of Applied Psychology 62 (4): 376-84. DOI:10.1037/00219010.62.4.376.

Meneses, G.D., and A.B. Palacio. 2005. "Recycling Behaviour: A Multidimensional Approach." Environment \& Behavior 37: 837-860. DOI: $10.1177 / 0013916505276742$.

Miafodzyeva, S., and N. Brandt. 2013. "Recycling Behaviour Among Households: Synthesizing Determinants via a Meta-Analysis." Waste and Biomass Valorization 4 (2): 221-35. DOI:10.1007/s12649-012-9144-4.

New York State Department of Environmental Conservation. 2014. New York's Bottle Bill. Accessed 3/9/14 from: http://www.dec.ny.gov/chemical/8500.html.

Nixon, Hilary, and Jean-Daniel M. Saphores. 2009. "Information and the Decision to Recycle: Results From a Survey of US Households." Journal of Environmental Planning and Management 52 (2): 257-77. DOI: 10.1080/09640560802666610.

Northeast Recycling Council. 2011. Disposal Bans \& Mandatory Recycling in the United States. Brattleboro, VT. Accessed March 6, 2014 from: www.nerc.org/documents/disposal_bans_mandatory_recycling_united_states.pdf.

Pickin, J. 2008. "Unit Pricing of Household Garbage in Melbourne: Improving Welfare, Reducing Garbage, or Neither? Waste Management \& Research 26: 508-514. DOI: 10.1177/0734242X08094950.

Reck, Barbara K. and T. E. Graedel 2012. "Challenges in Metals Recycling.” Science 337: 690-695.

Reid, Dennis H., Paul D. Luyben, Robert J. Rawers, and J. S. Bailey. 1976. "Newspaper Recycling Behavior: The Effects of Prompting and Proximity of Containers." Environment and Behavior 8 (3): 471-482. DOI: 10.1177/136327527600800307

Saphores, J.-D. M., H. Nixon, O. Ogunseitan, and A. A. Shapiro. 2006. "Household Willingness to Recycle Electronic Waste: An Application to California." Environment and Behavior 38 (2): 183-208.

Saphores, J.-D. M., O.A. Ogunseitan, and A. A. Shapiro. 2012. "Willingness to Engage in a Pro-Environmental Behavior: An Analysis of E-waste Recycling Based on a National Survey of U.S. Households." Resources, Conservation, and Recycling 60: 49-63. http://dx.doi.org/10.1016/j.resconrec.2011.12.003. 
Shaw, P.J., and S.J. Maynard. 2008. "The Potential of Financial Incentives to Enhance Householders' Curbside Recycling Behavior.” Waste Management 28: 17321741.

Seattle Public Utilities. 2013. Residential Recycled Materials Market Report. Accessed March 6, 2014 from:

http://www.seattle.gov/util/groups/public/@spu/@garbage/documents/webcontent /RESIDENTIA_200405051327316.pdf.

Schlesinger, Mark E. 2007. Aluminum Recycling. Boca Raton, FL: CRC Press.

Sidique, Shaufique F, Frank Lupi, and Satish V Joshi. 2010. "The Effects of Behavior and Attitudes on Drop-Off Recycling Activities." Resources, Conservation and Recycling 54 (3): 163-70. DOI:10.1016/j.resconrec.2009.07.012

Skumatz, Lisa. 2008. 2008. Pay as You Throw in the U.S.: Implementation, Impacts, and Experience. Waste Management 28(12): 2778-2785. doi: 10.1016/j.wasman.2008.03.033

State of Delaware. 2011. Retail Beverage Container License and Recycling Fee Accessed 3/9/14 from: http://revenue.delaware.gov/services/bottle.shtml.

Stavins, Robert N. 2001. "Experience with Market-Based Environmental Policy Instruments." Resources for the Future (01-59): 1-92.

Thompson, B. (2004). Exploratory and Confirmatory Factor Analysis. American Psychological Association, Washington, DC.

Tonn, Bruce, Paul D. Frymier, Dorian Stiefel, Leah Soro Skinner, and Methika Suraweera. 2014. "Toward an Infinitely Reusable, Recyclable, and Renewable Industrial Ecosystem.” Journal of Cleaner Production 66: 393-406. http://dx.doi.org/10.1016/j.jclepro.2013.11.008.

U.S. Environmental Protection Agency (EPA). 2013. Municipal Solid Waste in the United States: 2011 Facts and Figures. Office of Solid Waste, Washington, DC. EPA530-R-13-001.

U.S. Environmental Protection Agency (EPA). 2014. Municipal Solid Waste Generation, Recycling, and Disposal in the United States: Tables and Figures for 2012. Office of Resource Conversation and Recovery, February.

Van Haaren, Rob, Nickolas Themelis, and Nora Goldstein. 2010. "The State of Garbage in America." Biocycle 51 (10): 16-23.

Viscusi, W. Kip, Joel Huber, Jason Bell, and Caroline Cecot. 2013. Discontinuous Behavioral Responses to Recycling Laws and Plastic Water Bottle Deposits. American Law and Economics Review 15: 110-155.

Walls, Margaret. 2003. "The Role of Economics in Extended Producer Responsibility: Making Policy Choices and Setting Policy Goals." Resources for the Future March (03-11): 29.

Williams, R. 2006. Generalized ordered logit/partial proportional-odds models for ordinal dependent variables. Stata Journal 6: 58-82.

Yang, Hai-Lan, and Robert Innes. 2007 Economic Incentives and Residential Waste Management in Taiwan: An Empirical Investigation. Environmental \& Resource Economics 37: 489-519. 


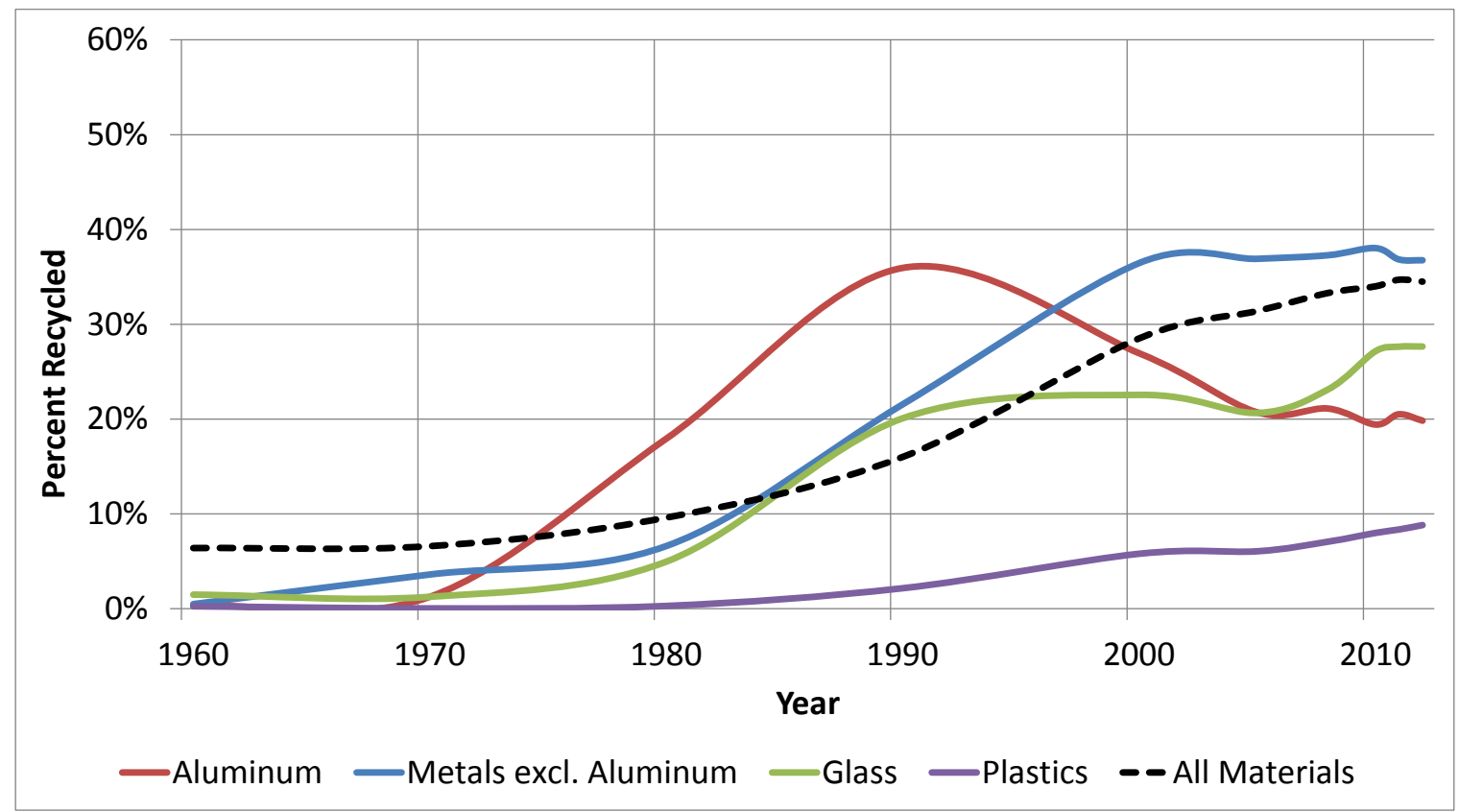

Panel A:Recycling rates for all materials and for four selected household materials

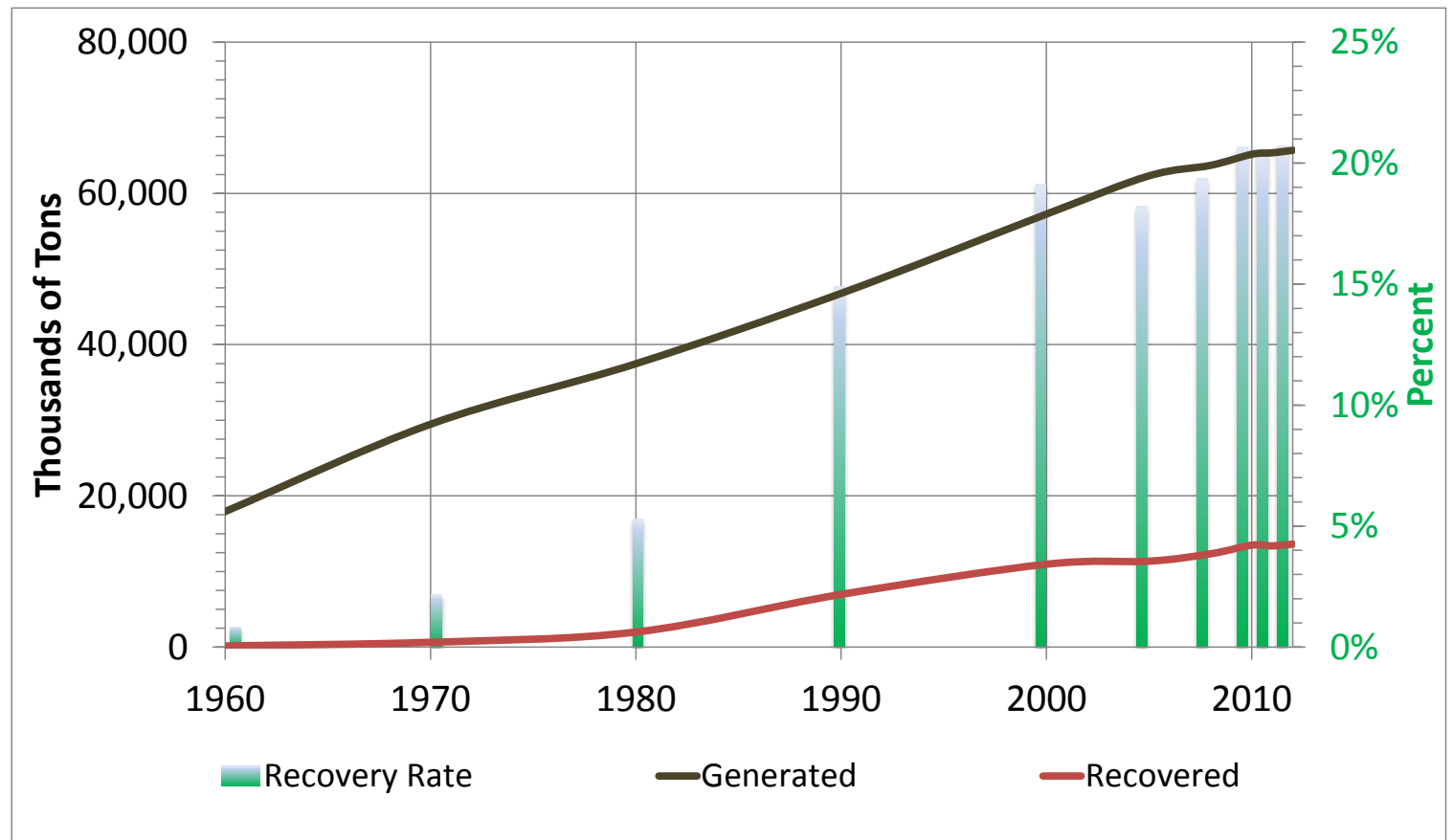

\section{Panel B: Percentage generated and recovered for glass, metal, and plastics}

Figure 1 U.S. Municipal Waste Stream Generation and Recycling Rates, 1960-2012 Source: U.S. Environmental Protection Agency (EPA). 2014. Municipal Solid Waste Generation, Recycling, and Disposal in the United States: Tables and Figures for 2012. Office of Resource Conversation and Recovery, February. 


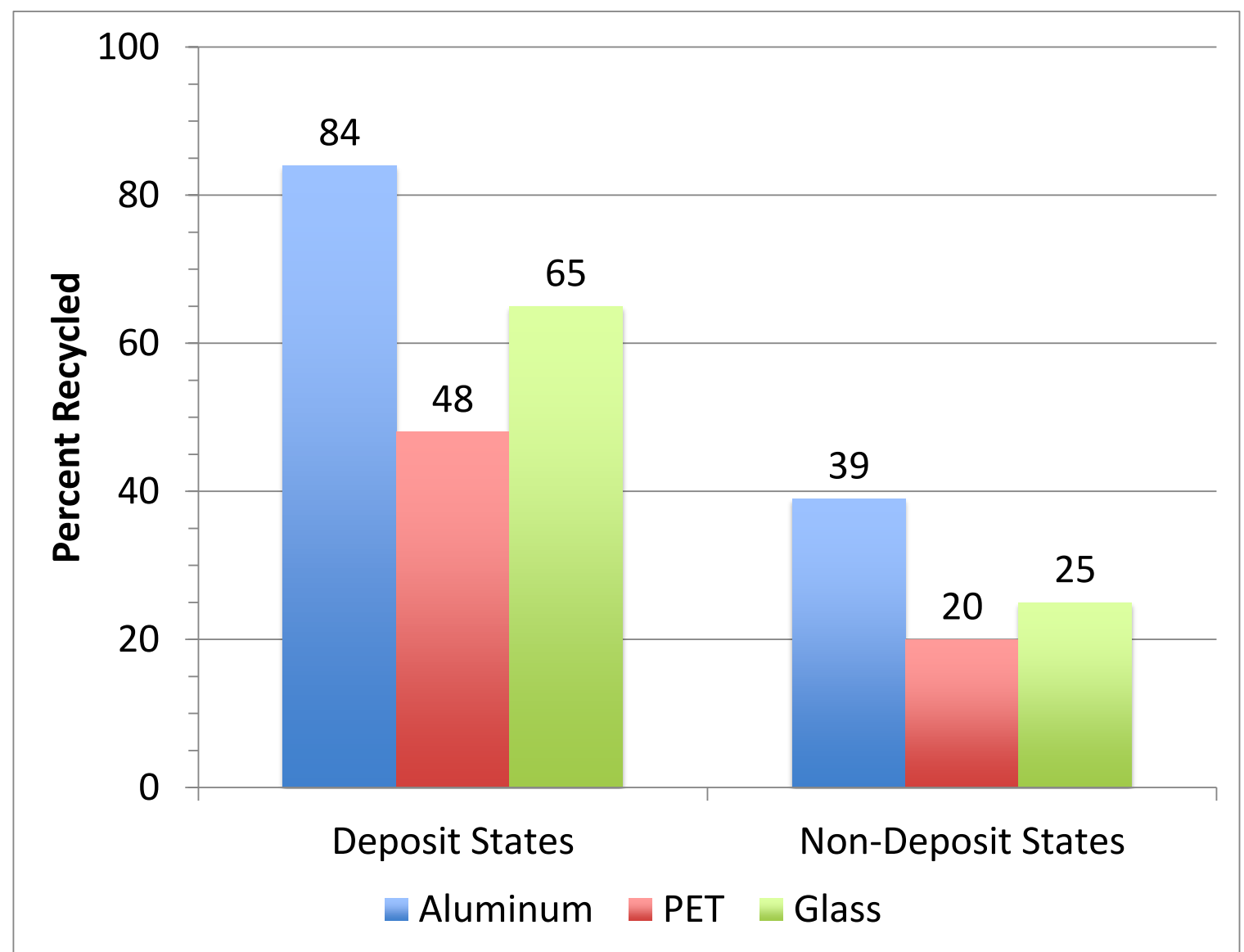

Figure 2 Comparison of Beverage Container Recycling Rates in States With and Without Bottle Bills

Source: Gitlitz, Jenny. 2013. Bottled Up: Beverage Container Recycling Stagnates (20002010), U.S. Container Recycling Rates \& Trends, 2013. Container Recycling Institute: Culver City, CA. 


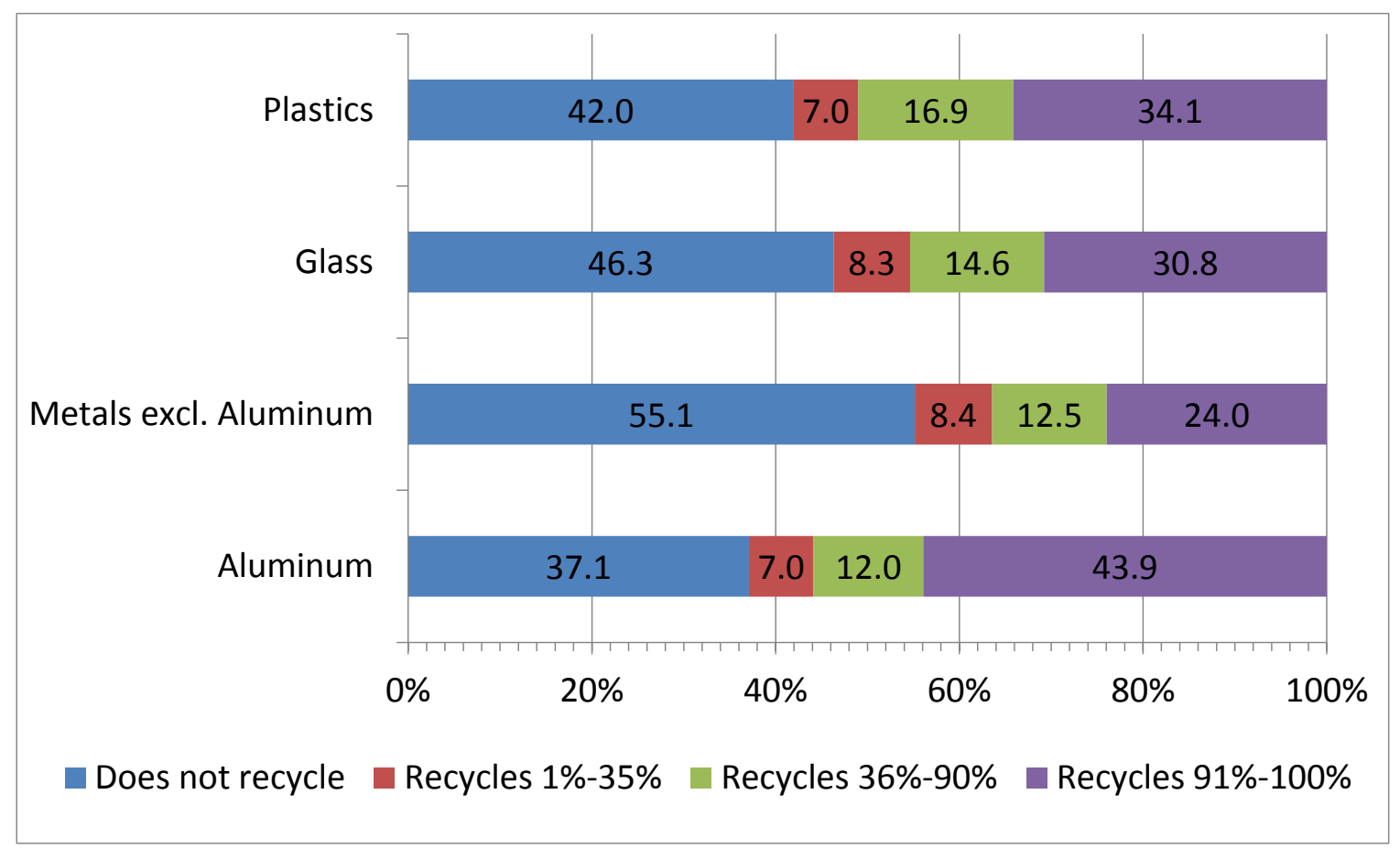

Figure 3 Percentage of Respondents by Recycling Category for Glass, Metals, and Plastics 
Table 1 Overview of State's Bottle Bills

\begin{tabular}{|c|c|c|c|}
\hline State & $\begin{array}{l}\text { Date Enacted / } \\
\text { Implemented }\end{array}$ & Containers \& Beverages Covered & Deposit Amount \\
\hline California & $1986 / 1987$ & $\begin{array}{l}\text { - Containers: Aluminum, glass, plastic and bi-metal. Exempts } \\
\text { refillables. } \\
\text { Beverages: Beer, malt, wine coolers \& distilled spirit coolers; all } \\
\text { non-alcoholic beverages except milk. Excluded: wine, 100\% fruit } \\
\text { juice >46 oz., } 100 \% \text { vegetable juice > 16oz. }\end{array}$ & $4 \phi<24$ oz. $; 8 \phi \geq 24 \mathrm{oz}^{\mathrm{a}}$ \\
\hline Connecticut & $1978 / 1980$ & $\begin{array}{l}\text { Containers: Glass, metal or plastic. Must be individual, separate, } \\
\text { and sealed. Containers over } 3 \text { liters containing noncarbonated } \\
\text { beverages and HDPE containers excluded. } \\
\text { Beverages: Beer, malt, carbonated soft drinks, and non-carbonated } \\
\text { beverages including bottled water. Excluded: juice, mineral water. }\end{array}$ & $5 \phi$ \\
\hline Delaware $^{\mathrm{b}}$ & 1982 / 1983 & $\begin{array}{l}\text { - Containers: All beverage containers under } 2 \text { quarts. Excluded } \\
\text { aluminum. } \\
\text { - Beverages: Beer, malt, ale, soft drinks, mineral water, and soda } \\
\text { water. }\end{array}$ & $5 \phi$ \\
\hline Hawaii & $2002 / 2005$ & $\begin{array}{l}\text { - Containers: Aluminum, glass, plastic (PET and HDPE only) and bi- } \\
\text { metal. } \\
\text { - Beverages: Beer, malt beverages, mixed spirits, and mixed wine. } \\
\text { All nonalcoholic drinks, except for milk or dairy products. }\end{array}$ & $5 \phi$ \\
\hline Iowa & 1978 / 1979 & $\begin{array}{l}\text { - Containers: Any sealed glass, plastic, or metal bottle, can, jar or } \\
\text { carton containing a beverage. } \\
\text { - Beverages: Beer, carbonated soft drinks and mineral water, wine } \\
\text { coolers, wine, and liquor. }\end{array}$ & $5 \phi$ \\
\hline Maine & $1976 / 1978$ & $\begin{array}{l}\text { Containers: Glass, metal or plastic, containing } 4 \text { liters or less, } \\
\text { excluding aseptics (must be sealed). } \\
\text { - Beverages: All except dairy products and unprocessed cider. }\end{array}$ & $5 \phi ; 15 \phi$ for wine/liquor \\
\hline
\end{tabular}


Massachusetts

$1981 / 1983$

Michigan

$1976 / 1978$

New York

$1982 / 1983$

Oregon

$1971 / 1972$

Vermont

$1972 / 1973$
- Containers: Glass, metal, plastic, or combination. Excluded: biodegradables.

- Beverages: Beer, malt, carbonated soft drinks, and mineral water.

- Containers: Glass, metal, paper, plastic container, or combination, under 1 gallon.

- Beverages: Beer, soft drinks, carbonated and mineral water, wine coolers, canned cocktails.

- Containers: Glass, metal, paper, plastic, or combination, under 1 gallon.

- Beverages: Carbonated soft drinks, soda water, beer, malt, and wine coolers. $^{\mathrm{c}}$

- Containers: Glass, metal, or plastic. Must be individual, separate, and sealed.

- Beverages: Beer, malt, carbonated soft drinks, and mineral water. ${ }^{\mathrm{d}}$

- Containers: Glass, metal, paper, plastic or combination. Excluded: biodegradable.

- Beverages: Beer, malt, carbonated soft drinks, mixed wine drinks, and liquor.
$10 \varnothing$

$2 \notin$ refillable; $10 \notin$ all others

$5 \phi ; 15 \phi$ for liquor

\footnotetext{
Sources: Container Recycling Institute. 2013. Bottle Bills in the USA. Accessed 3/9/14 from: http://www.bottlebill.org/legislation/usa.htm. California Department of Resources Recycling and Recovery. 2014. Beverages Subject to California Refund Value. Accessed 4/2/14 from http://www.calrecycle.ca.gov/Publications/Detail.aspx?PublicationID=1475. State of Delaware. 2011. Retail Beverage Container License and Recycling Fee Accessed 3/9/14 from: http://revenue.delaware.gov/services/bottle.shtml. New York State Department of Environmental Conservation. 2014. New York's Bottle Bill. Accessed 3/9/14 from: http://www.dec.ny.gov/chemical/8500.html.

Notes: This table reflects regulations in place in 2006 when our survey was conducted.

${ }^{a}$ Deposit increased to $5 \varnothing$ and $10 \phi$, respectively, in 2007.

${ }^{\mathrm{b}}$ Regulation repealed in 2010. Converted to a recycling fee only (no refund) program.

${ }^{\mathrm{c}}$ Water added in 2009.

${ }^{\mathrm{d}}$ Non-carbonated water added in 2009. Expanded to all beverages except wine, liquor, milk and milk substitutes in 2011.
} 
Table 2: Multinomial Logit for Aluminum and Plastics Recycling

\begin{tabular}{|c|c|c|c|c|c|c|}
\hline \multirow{2}{*}{ Variables } & \multicolumn{3}{|c|}{ Aluminum $(\mathrm{n}=2,051)$} & \multicolumn{3}{|c|}{ Plastics $(n=2,033)$} \\
\hline & $\mathrm{OR}_{\mathrm{L} \mid \mathrm{N}}$ & $\mathrm{OR}_{\mathrm{M} \mid \mathrm{N}}$ & $\mathrm{OR}_{\mathrm{H} \mid \mathrm{N}}$ & $\mathrm{OR}_{\mathrm{L} \mid \mathrm{N}}$ & $\mathrm{OR}_{\mathrm{M} \mid \mathrm{N}}$ & $\mathrm{OR}_{\mathrm{H} \mid \mathrm{N}}$ \\
\hline \multicolumn{7}{|l|}{ External variables } \\
\hline 1 if respondent age is 18 to 29 & $0.54 * *$ & 0.73 & $0.47 * * *$ & 0.66 & $0.59 * *$ & $0.58 * *$ \\
\hline 1 if respondent age is 30 to 44 & 0.65 & 0.85 & $0.62 * *$ & $0.57 * *$ & 0.78 & 0.79 \\
\hline 1 if respondent age is $60+$ & $0.55^{*}$ & 0.70 & 0.75 & 0.59 & $0.60 *$ & 0.66 \\
\hline 1 if person $>=65$ in household & 1.21 & 1.07 & $1.41^{*}$ & 1.01 & 0.95 & 1.45 \\
\hline Log of household size & 1.29 & 1.12 & 1.19 & $1.62 * *$ & $1.53^{* *}$ & 1.18 \\
\hline 1 if respondent gender is female & 1.15 & 1.28 & 1.04 & 0.87 & 1.24 & 1.23 \\
\hline 1 if respondent is African-American, non-Hispanic & 0.90 & $0.54 * *$ & $0.41 * * *$ & 0.96 & $0.62 *$ & $0.43 * * *$ \\
\hline 1 if respondent is Hispanic & 1.07 & $1.73 *$ & 0.89 & 0.87 & 1.58 & 1.10 \\
\hline 1 if respondent is other ethnicity & 1.67 & 1.08 & 0.79 & 1.50 & 1.66 & 0.88 \\
\hline 1 if respondent education is less than high school & 0.62 & 0.95 & 0.90 & 1.10 & 0.62 & 0.78 \\
\hline 1 if respondent education is high school & 0.90 & 0.80 & 0.87 & 0.78 & $0.65^{* *}$ & 0.90 \\
\hline 1 if respondent education is some college & 1.28 & 1.08 & 0.93 & 1.09 & 0.87 & 0.93 \\
\hline Logarithm of household income in $\$ 1,000$ & 1.05 & 1.07 & 1.10 & 1.04 & 1.13 & 1.08 \\
\hline 1 if household income $>=\$ 175 \mathrm{~K}$ & 0.59 & 1.92 & 1.46 & 1.28 & 1.97 & 1.43 \\
\hline 1 if dual income household & 1.06 & 1.24 & 1.21 & $0.56^{* *}$ & 0.99 & 1.04 \\
\hline 1 if single-family house & 1.10 & 0.91 & $1.46^{* *}$ & 1.09 & 1.05 & 1.28 \\
\hline 1 if rural area & 1.23 & 0.98 & $1.46^{* *}$ & 1.38 & 1.03 & $1.46^{* *}$ \\
\hline \multicolumn{7}{|l|}{ Internal variables } \\
\hline Perceived obstacles to recycling factor: $1=$ low & $7.75 * * *$ & $9.92 * * *$ & $128.32 * * *$ & $4.95 * * *$ & $18.71 * * *$ & $231.34 * * *$ \\
\hline Perceived benefits of recycling factor: $1=$ high & 2.22 & $2.94 * *$ & $7.90 * * *$ & 2.43 & $3.24 * *$ & $11.20 * * *$ \\
\hline Don't blame households like mine for excess trash: agree $=1$ & 1.34 & 1.04 & 1.12 & $1.64 * *$ & 1.21 & 1.16 \\
\hline My responsibility is to my family and myself: agree $=1$ & $1.85 * * *$ & 1.01 & 0.89 & 1.01 & 0.85 & 0.76 \\
\hline I feel a moral obligation to recycle: agree $=1$ & $3.64 * * *$ & $4.45 * * *$ & $3.59 * * *$ & $4.91 * * *$ & $3.44 * * *$ & $4.11 * * *$ \\
\hline \multicolumn{7}{|l|}{ Policy variables } \\
\hline 1 if curbside recycling available & $8.26 * * *$ & $6.68 * * *$ & $6.61 * * *$ & $6.87 * * *$ & $7.13 * * *$ & $19.39 * * *$ \\
\hline 1 if curbside recycling mandatory & $2.13 * *$ & 1.21 & $1.86 * *$ & $3.33 * * *$ & $2.21 * * *$ & $2.82 * * *$ \\
\hline 1 if distance to nearest drop-off collection center $\leq 5 \mathrm{mi}$ & 1.57 & $2.34 * * *$ & $1.87 * * *$ & $3.35 * * *$ & $3.83^{* * *} *$ & $6.31 * * *$ \\
\hline 1 if state has a bottle bill & $1.80 * *$ & $1.77 * * *$ & $2.04 * * *$ & $1.61 *$ & $2.33 * * *$ & $3.07 * * *$ \\
\hline 1 if marginal pricing for household waste & 1.05 & 0.78 & 1.06 & 1.09 & 1.05 & $1.65^{*}$ \\
\hline
\end{tabular}


Table 3: Generalized Ordered Logit for Metals other than Aluminum and Glass Recycling

\begin{tabular}{|c|c|c|c|c|c|c|}
\hline \multirow[b]{2}{*}{ Variables } & \multicolumn{3}{|c|}{ Other Metals $(n=1,921)$} & \multicolumn{3}{|c|}{ Glass $(n=2,037)$} \\
\hline & $\mathrm{OR}_{>\mathrm{N} \mid \leq \mathrm{N}}$ & $\mathrm{OR}_{>\mathrm{L} \mid \leq \mathrm{L}}$ & $\mathrm{OR}_{>\mathrm{M} \mid \leq \mathrm{M}}$ & $\mathrm{OR}_{>\mathrm{N} \mid \leq \mathrm{N}}$ & $\mathrm{OR}_{>\mathrm{L} \mid \leq \mathrm{L}}$ & $\mathrm{OR}_{>\mathrm{M} \mid \leq \mathrm{M}}$ \\
\hline \multicolumn{7}{|l|}{ External variables } \\
\hline 1 if respondent age is 18 to 29 & $0.66^{* * *}$ & $0.66^{* * *}$ & $0.66 * * *$ & 0.98 & 0.95 & $0.60 * * *$ \\
\hline 1 if respondent age is 30 to 44 & 0.98 & 0.98 & 0.98 & 1.15 & 1.14 & 0.78 \\
\hline 1 if respondent age is $60+$ & 0.79 & 0.97 & 1.18 & 0.79 & 0.79 & 0.79 \\
\hline 1 if person $>=65$ in household & $1.46^{* *}$ & $1.46^{* *}$ & $1.46^{* *}$ & 1.17 & 1.17 & 1.17 \\
\hline Log of household size & 0.96 & 0.96 & 0.96 & 1.08 & 1.08 & 1.08 \\
\hline 1 if respondent gender is female & 1.05 & 1.05 & 1.05 & $1.23 * *$ & $1.23^{* *}$ & $1.23 * *$ \\
\hline 1 if respondent is African-American, non-Hispanic & $0.48 * * *$ & $0.48 * * *$ & $0.48 * * *$ & $0.39 * * *$ & $0.39 * * *$ & $0.39 * * *$ \\
\hline 1 if respondent is Hispanic & 0.93 & 0.93 & 0.93 & 0.96 & 0.96 & 0.96 \\
\hline 1 if respondent is other ethnicity & 0.90 & 0.90 & 0.90 & 0.92 & 0.92 & 0.92 \\
\hline 1 if respondent education is less than high school & 1.06 & 1.06 & 1.06 & 0.91 & 0.91 & 0.91 \\
\hline 1 if respondent education is high school & 1.07 & 1.07 & 1.07 & 0.98 & 0.98 & 0.98 \\
\hline 1 if respondent education is some college & 1.01 & 1.01 & 1.01 & 0.87 & $0.72 * *$ & 0.89 \\
\hline Logarithm of household income in $\$ 1,000$ & 1.02 & 1.02 & 1.02 & 1.09 & 1.09 & 1.09 \\
\hline 1 if household income $>=\$ 175 \mathrm{~K}$ & 0.99 & 0.99 & 0.99 & 1.53 & 1.53 & 1.53 \\
\hline 1 if dual income household & $1.38 * * *$ & $1.38 * * *$ & $1.38 * * *$ & 1.18 & 1.18 & 1.18 \\
\hline 1 if single-family house & 1.11 & 1.11 & 1.11 & 1.11 & 1.11 & 1.11 \\
\hline 1 if rural area & $1.36 * *$ & $1.63^{* * *}$ & $2.08 * * *$ & 1.05 & 1.17 & $1.60 * * *$ \\
\hline \multicolumn{7}{|l|}{ Internal variables } \\
\hline Perceived obstacles to recycling factor: $1=$ low & $15.96 * * *$ & $27.53 * * *$ & $38.70 * * *$ & $39.07 * * *$ & $39.07 * * *$ & $39.07 * * *$ \\
\hline Perceived benefits of recycling factor: $1=$ high & $5.75 * * *$ & $3.17 * * *$ & $2.22 *$ & $3.69 * * *$ & $3.69 * * *$ & $3.69 * * *$ \\
\hline Don't blame households like mine for excess trash: agree $=1$ & 1.07 & 1.07 & 1.07 & 1.13 & 1.13 & 1.13 \\
\hline My responsibility is to my family and myself: agree $=1$ & 0.94 & 0.94 & 0.94 & 0.83 & 0.83 & 0.83 \\
\hline I feel a moral obligation to recycle: agree $=1$ & $2.15 * * *$ & $2.15 * * *$ & $2.15 * * *$ & $3.80 * * *$ & $3.04 * * *$ & $1.91 * * *$ \\
\hline \multicolumn{7}{|l|}{ Policy variables } \\
\hline 1 if curbside recycling available & $4.96 * * *$ & $4.96 * * *$ & $4.96 * * *$ & $9.77 * * *$ & $7.32 * * *$ & $6.44 * * *$ \\
\hline 1 if curbside recycling mandatory & $1.99 * * *$ & $1.38 * *$ & $1.46^{* *}$ & $2.93 * * *$ & $1.72 * * *$ & $1.97 * * *$ \\
\hline 1 if distance to nearest drop-off collection center $\leq 5 \mathrm{mi}$ & $2.70 * * *$ & $2.70 * * *$ & $2.70 * * *$ & $5.01 * * *$ & $3.93 * * *$ & $2.70 * * *$ \\
\hline 1 if state has a bottle bill & $2.02 * * *$ & $1.50 * * *$ & $1.28 *$ & $1.94 * * *$ & $1.94 * * *$ & $1.94 * * *$ \\
\hline 1 if marginal pricing for household waste & $1.55 * *$ & $1.55^{* *}$ & $1.55^{* *}$ & 1.21 & 1.21 & 1.21 \\
\hline
\end{tabular}


Table 4: Multinomial Logit without Internal Variables for Aluminum and Plastics Recycling

\begin{tabular}{|c|c|c|c|c|c|c|}
\hline \multirow[b]{2}{*}{ Variables } & \multicolumn{3}{|c|}{ Aluminum $(\mathrm{n}=2,051)$} & \multicolumn{3}{|c|}{ Plastics $(n=2,033)$} \\
\hline & $\mathrm{OR}_{\mathrm{L} \mid \mathrm{N}}$ & $\mathrm{OR}_{\mathrm{M} \mid \mathrm{N}}$ & $\mathrm{OR}_{\mathrm{H} \mid \mathrm{N}}$ & $\mathrm{OR}_{\mathrm{L} \mid \mathrm{N}}$ & $\mathrm{OR}_{\mathrm{M} \mid \mathrm{N}}$ & $\mathrm{OR}_{\mathrm{H} \mid \mathrm{N}}$ \\
\hline \multicolumn{7}{|l|}{ External variables } \\
\hline 1 if respondent age is 18 to 29 & $0.50 * *$ & $0.64 *$ & $0.41 * * *$ & $0.55 * *$ & $0.50 * * *$ & $0.47 * * *$ \\
\hline 1 if respondent age is 30 to 44 & 0.66 & 0.82 & $0.62 * * *$ & $0.53 * *$ & 0.74 & $0.73^{*}$ \\
\hline 1 if respondent age is $60+$ & 0.63 & 0.77 & 0.85 & 0.68 & 0.69 & 0.78 \\
\hline 1 if person $>=65$ in household & 1.34 & 1.17 & $1.49 * *$ & 1.08 & 1.01 & $1.48^{*}$ \\
\hline Log of household size & 1.23 & 1.03 & 1.06 & $1.50 *$ & $1.41 * *$ & 1.03 \\
\hline 1 if respondent gender is female & 1.07 & $1.31^{*}$ & 1.04 & 0.86 & 1.22 & 1.18 \\
\hline 1 if respondent is African-American, non-Hispanic & 0.86 & $0.50 * *$ & $0.34 * * *$ & 0.93 & $0.57 * *$ & $0.34 * * *$ \\
\hline 1 if respondent is Hispanic & 1.36 & $2.03 * *$ & 1.10 & 0.98 & $1.77 *$ & 1.33 \\
\hline 1 if respondent is other ethnicity & 1.72 & 1.13 & 0.81 & 1.48 & $1.64 *$ & 0.87 \\
\hline 1 if respondent education is less than high school & 0.60 & 0.80 & 0.70 & 1.05 & $0.56^{* *}$ & 0.65 \\
\hline 1 if respondent education is high school & 0.80 & $0.66^{*}$ & $0.70 * *$ & 0.69 & $0.55^{* * *}$ & 0.74 \\
\hline 1 if respondent education is some college & 1.28 & 1.03 & 0.87 & 1.09 & 0.84 & 0.88 \\
\hline Logarithm of household income in $\$ 1,000$ & 1.06 & 1.11 & $1.24 * *$ & 1.06 & $1.19^{*}$ & $1.28 * *$ \\
\hline 1 if household income $>=\$ 175 \mathrm{~K}$ & 0.50 & 1.91 & 1.20 & 1.11 & 1.83 & 1.07 \\
\hline 1 if dual income household & 1.01 & 1.16 & 1.06 & $0.57 * *$ & 0.97 & 0.94 \\
\hline 1 if single-family house & 1.13 & 0.94 & $1.53 * * *$ & 1.14 & 1.10 & $1.42 * *$ \\
\hline 1 if rural area & 1.34 & 1.05 & $1.50 * * *$ & $1.55 * *$ & 1.11 & $1.50 * * *$ \\
\hline \multicolumn{7}{|l|}{ Policy variables } \\
\hline 1 if curbside recycling available & $9.90 * * *$ & $8.20 * * *$ & $10.36 * * *$ & $7.62 * * *$ & $8.15^{* * * *}$ & $24.93 * * *$ \\
\hline 1 if curbside recycling mandatory & $2.64 * * *$ & 1.48 & $2.41 * * *$ & $3.73 * * *$ & $2.51 * * *$ & $3.42 * * *$ \\
\hline 1 if distance to nearest drop-off collection center $\leq 5 \mathrm{mi}$ & $1.85^{*}$ & $2.73 * * *$ & $2.49 * * *$ & $3.68 * * *$ & $4.17 * * *$ & $7.33 * * *$ \\
\hline 1 if state has a bottle bill & $1.71 * *$ & $1.60 * *$ & $1.79 * * *$ & 1.41 & $1.93 * * *$ & $2.29 * * *$ \\
\hline 1 if marginal pricing for household waste & 1.16 & 0.83 & 1.12 & 1.15 & 1.01 & $1.52 *$ \\
\hline
\end{tabular}


Table 5: Generalized Ordered Logit without Internal Variables for Metals other than Aluminum and Glass Recycling

\begin{tabular}{|c|c|c|c|c|c|c|}
\hline \multirow[b]{2}{*}{ Variables } & \multicolumn{3}{|c|}{ Other Metals $(n=1,921)$} & \multicolumn{3}{|c|}{ Glass $(n=2,037)$} \\
\hline & $\mathrm{OR}_{>\mathrm{N} \mid \leq \mathrm{N}}$ & $\mathrm{OR}_{>\mathrm{L} \mid \leq \mathrm{L}}$ & $\mathrm{OR}_{>\mathrm{M} \mid \leq \mathrm{M}}$ & $\mathrm{OR}_{>\mathrm{N} \mid \leq \mathrm{N}}$ & $\mathrm{OR}_{>\mathrm{L} \mid \leq \mathrm{L}}$ & $\mathrm{OR}_{>\mathrm{M} \mid \leq \mathrm{M}}$ \\
\hline \multicolumn{7}{|l|}{ External variables } \\
\hline 1 if respondent age is 18 to 29 & $0.56^{* * *}$ & $0.56^{* * *}$ & $0.56^{* * *}$ & $0.62 * * *$ & $0.62 * * *$ & $0.62 * * *$ \\
\hline 1 if respondent age is 30 to 44 & 0.92 & 0.92 & 0.92 & 0.90 & 0.90 & 0.90 \\
\hline 1 if respondent age is $60+$ & 0.86 & 1.03 & 1.20 & 0.89 & 0.89 & 0.89 \\
\hline 1 if person $>=65$ in household & $1.41 * *$ & $1.41 * *$ & $1.41 * *$ & 1.22 & 1.22 & 1.22 \\
\hline Log of household size & 0.88 & 0.88 & 0.88 & 0.99 & 0.99 & 0.99 \\
\hline 1 if respondent gender is female & 1.05 & 1.05 & 1.05 & $1.20 *$ & $1.20 *$ & $1.20^{*}$ \\
\hline 1 if respondent is African-American, non-Hispanic & $0.37 * * *$ & $0.37 * * *$ & $0.37 * * *$ & $0.33 * * *$ & $0.33 * * *$ & $0.33 * * *$ \\
\hline 1 if respondent is Hispanic & 1.07 & 1.07 & 1.07 & 1.11 & 1.11 & 1.11 \\
\hline 1 if respondent is other ethnicity & 0.85 & 0.85 & 0.85 & 0.88 & 0.88 & 0.88 \\
\hline 1 if respondent education is less than high school & 0.92 & 0.92 & 0.92 & 0.78 & 0.78 & 0.78 \\
\hline 1 if respondent education is high school & 0.92 & 0.92 & 0.92 & 0.84 & 0.84 & 0.84 \\
\hline 1 if respondent education is some college & 0.97 & 0.97 & 0.97 & 0.81 & 0.81 & 0.81 \\
\hline Logarithm of household income in $\$ 1,000$ & $1.15^{* *}$ & $1.15^{* *}$ & $1.15^{* *}$ & $1.25 * * *$ & $1.25 * * *$ & $1.25 * * *$ \\
\hline 1 if household income $>=\$ 175 \mathrm{~K}$ & 0.85 & 0.85 & 0.85 & 1.14 & 1.14 & 1.14 \\
\hline 1 if dual income household & $1.24 *$ & $1.24 *$ & $1.24 *$ & 1.06 & 1.06 & 1.06 \\
\hline 1 if single-family house & 1.21 & 1.21 & 1.21 & 1.20 & 1.20 & 1.20 \\
\hline 1 if rural area & $1.58 * * *$ & $1.58 * * *$ & $1.58 * * *$ & 1.13 & 1.20 & $1.53 * * *$ \\
\hline \multicolumn{7}{|l|}{ Policy variables } \\
\hline 1 if curbside recycling available & $7.60 * * *$ & $7.60 * * *$ & $7.60 * * *$ & $12.42 * * *$ & $12.42 * * *$ & $12.42 * * *$ \\
\hline 1 if curbside recycling mandatory & $2.39 * * *$ & $1.62 * * *$ & $1.57 * * *$ & $3.80 * * *$ & $2.09 * * *$ & $2.23 * * *$ \\
\hline 1 if distance to nearest drop-off collection center $\leq 5 \mathrm{mi}$ & $3.73 * * *$ & $3.73 * * *$ & $3.73 * * *$ & $5.32 * * *$ & $5.32 * * *$ & $5.32 * * *$ \\
\hline 1 if state has a bottle bill & $1.88 * * *$ & $1.46^{* * *}$ & $1.29 * *$ & $1.71 * * *$ & $1.71 * * *$ & $1.71 * * *$ \\
\hline 1 if marginal pricing for household waste & $1.49 * *$ & $1.49 * *$ & $1.49 * *$ & 1.16 & 1.16 & 1.16 \\
\hline
\end{tabular}


Supplemental material 
Supplementary Table 1: Characteristics of Survey Respondents vs. U.S. population

\begin{tabular}{|c|c|c|c|}
\hline Characteristic & Category & $\begin{array}{l}\text { Percent of } \\
\text { respondents } \\
(\mathrm{n}=2,136)\end{array}$ & $\begin{array}{r}\text { Percent of U.S. } \\
\text { Population }\end{array}$ \\
\hline \multirow[t]{4}{*}{ Age } & 18-29: & 19.4 & 22.1 \\
\hline & 30-44; & 26.2 & 26.8 \\
\hline & 45-59: & 28.0 & 27.5 \\
\hline & $\geq 60$ & 26.3 & 23.6 \\
\hline \multirow[t]{2}{*}{ Gender } & Male: & 48.0 & 48.5 \\
\hline & Female: & 52.0 & 51.5 \\
\hline \multirow[t]{5}{*}{ Marital status } & Married: & 58.0 & 50.2 \\
\hline & Divorced: & 12.5 & 10.5 \\
\hline & Widowed: & 4.8 & 6.1 \\
\hline & Separated: & 1.8 & 2.2 \\
\hline & Single (never married): & 22.9 & 31.0 \\
\hline \multirow[t]{5}{*}{ Race/ethnicity } & White: & 77.7 & 64.7 \\
\hline & Hispanic: & 7.3 & 15.7 \\
\hline & Black, African-American: & 8.5 & 12.2 \\
\hline & Two or more races: & 2.8 & 1.8 \\
\hline & Other: & 3.7 & 5.7 \\
\hline \multirow[t]{4}{*}{ Education } & Less than high school: & 11.4 & 14.9 \\
\hline & High school: & 33.3 & 29.0 \\
\hline & Some college: & 29.5 & 28.1 \\
\hline & BS/BA degree or higher: & 25.8 & 27.9 \\
\hline \multirow{6}{*}{$\begin{array}{l}\text { Household } \\
\text { income }\end{array}$} & $<\$ 10 \mathrm{~K}:$ & 8.1 & 7.8 \\
\hline & $\$ 10 \mathrm{~K}-24 \mathrm{~K}:$ & 18.4 & 17.6 \\
\hline & $\$ 25 \mathrm{~K}-49 \mathrm{~K}:$ & 32.8 & 26.6 \\
\hline & $\$ 50 \mathrm{~K}-74 \mathrm{~K}:$ & 19.8 & 20 \\
\hline & \$75K-99K: & 11.6 & 13.3 \\
\hline & $\geq \$ 100 \mathrm{~K}:$ & 9.3 & 22.5 \\
\hline \multirow[t]{3}{*}{ Homeownership } & Own: & 70.0 & 66.6 \\
\hline & Rent: & 24.4 & 33.4 \\
\hline & Other: & 5.7 & NA \\
\hline \multirow[t]{5}{*}{ Type of dwelling } & Single-family detached: & 67.2 & 63.2 \\
\hline & Duplex: & 5.5 & 5.9 \\
\hline & Mobile home: & 7.9 & 6.1 \\
\hline & Apartment/condominium: & 17.6 & 24.7 \\
\hline & Other: & 1.8 & 0.1 \\
\hline \multirow[t]{5}{*}{ Household size } & 1: & 20.7 & 27.2 \\
\hline & 2: & 38.8 & 33.4 \\
\hline & 3: & 17.2 & 15.9 \\
\hline & 4: & 14.0 & 13.5 \\
\hline & $>4:$ & 9.3 & 9.8 \\
\hline
\end{tabular}

Source: U.S. Census Bureau; American Community Survey, 2006-2010

(http://factfinder2.census.gov/home). Percentages may not sum to $100 \%$ due to rounding. 
Supplementary Table 2: Factor Analysis Summary

\begin{tabular}{|c|c|c|c|c|c|c|c|}
\hline \multicolumn{2}{|l|}{ Item } & SA & MA & $\mathbf{U}$ & MD & SD & $\begin{array}{r}\text { Factor } \\
\text { Loading }\end{array}$ \\
\hline \multicolumn{8}{|c|}{ Perceived obstacles to recycling } \\
\hline 1 & $\begin{array}{l}\text { Finding room to store } \\
\text { recyclable materials is a } \\
\text { problem: agree }=1\end{array}$ & 18.57 & 32.27 & 11.4 & 23.97 & 13.79 & 0.6766 \\
\hline 2 & $\begin{array}{l}\text { Storing recyclable } \\
\text { materials at home is } \\
\text { unsanitary: agree }=1\end{array}$ & 8.51 & 25.39 & 17.4 & 30.42 & 18.29 & 0.7011 \\
\hline 3 & $\begin{array}{l}\text { Recycling drop-off centers } \\
\text { are too far away: agree }=1\end{array}$ & 11.81 & 20.66 & 27.72 & 22.31 & 17.51 & 0.4054 \\
\hline 4 & $\begin{array}{l}\text { Storing recyclable } \\
\text { materials at home is safe: } \\
\text { disagree }=1\end{array}$ & 22.63 & 34.46 & 25.31 & 12.49 & 5.12 & 0.5292 \\
\hline 5 & $\begin{array}{l}\text { The problem with } \\
\text { recycling is finding time to } \\
\text { do it: agree }=1\end{array}$ & 7.65 & 24.88 & 10.89 & 31.6 & 24.98 & 0.6104 \\
\hline \multicolumn{8}{|c|}{ Perceived benefits of recycling } \\
\hline 6 & $\begin{array}{l}\text { Recycling substantially } \\
\text { reduces the use of } \\
\text { landfills: disagree }=1\end{array}$ & 42.85 & 34.01 & 16.6 & 4.19 & 2.35 & 0.5954 \\
\hline 7 & $\begin{array}{l}\text { Recycling conserves } \\
\text { natural resources: } \\
\text { disagree }=1\end{array}$ & 47.27 & 35.90 & 13.30 & 1.64 & 1.88 & 0.6506 \\
\hline 8 & $\begin{array}{l}\text { Recycling won't make } \\
\text { much of a difference in } \\
\text { environmental quality: } \\
\text { agree=1 }\end{array}$ & 2.72 & 6.57 & 15.4 & 33.94 & 41.36 & 0.5508 \\
\hline 9 & $\begin{array}{l}\text { Recycling creates jobs: } \\
\text { disagree }=1\end{array}$ & 27.79 & 43.80 & 23.85 & 2.91 & 1.64 & 0.5431 \\
\hline
\end{tabular}

Notes.

1. SA, MA, U, MD, SD refer respectively to "Strongly Agree", "Mildly Agree", "Unsure",

"Mildly Disagree", and "Strongly Disagree".

2. To select the number of factors to consider, we relied on the Kaiser criterion: we retained only factors corresponding to eigenvalues greater than 1 .

3. After calculating each factor using the coefficients ("loadings") in the last column above, we normalized them so they are between 0 and 1 , where 1 indicates a favorable disposition toward recycling.

4. Both factors pass common specification tests (Thompson, 2004): the Bartlett test for sphericity strongly rejects the null hypothesis that these items are not correlated $(\mathrm{p}<0.001)$ for both factors; the Kaiser-Meyer Olkin (KMO) statistics, which equals 0.733 and 0.741 for obstacles to recycling and benefits of recycling respectively, indicate that correlations are not excessive (KMO ranges between 0 and 1 and should be at least 0.6); and values of Cronbach's alpha, which measures factor reliability, are adequate with values of 0.733 and 0.700 for recycling obstacles and benefits respectively (a value $\geq 0.7$ is typically required). 


\section{Supplementary Table 3: Summary Statistics}

\begin{tabular}{|c|c|c|c|c|c|}
\hline Variables & $\mathrm{N}$ & $\min$ & $\max$ & mean & s.d. \\
\hline \multicolumn{6}{|l|}{ Dependent variables } \\
\hline$\%$ Aluminum recycled & 2,108 & 1 & 4 & 2.627 & 1.362 \\
\hline$\%$ Other metals (not Aluminum) recycled & 1,971 & 1 & 4 & 2.052 & 1.278 \\
\hline$\%$ Glass recycled & 2,092 & 1 & 4 & 2.298 & 1.323 \\
\hline$\%$ Plastics recycled & 2,090 & 1 & 4 & 2.432 & 1.330 \\
\hline \multicolumn{6}{|l|}{ Socio-economic characteristics } \\
\hline Age 18-29: Yes=1 & 2,136 & 0 & 1 & 0.194 & 0.396 \\
\hline Age 30-44: Yes=1 & 2,136 & 0 & 1 & 0.262 & 0.440 \\
\hline Age $60+:$ Yes $=1$ & 2,136 & 0 & 1 & 0.263 & 0.440 \\
\hline 1 if person $>=65$ in household & 2,136 & 0 & 1 & 0.264 & 0.441 \\
\hline Gender: Female $=1$ & 2,136 & 0 & 1 & 0.520 & 0.500 \\
\hline 1 if African-American, non-Hispanic & 2,136 & 0 & 1 & 0.085 & 0.279 \\
\hline 1 if other ethnicity & 2,136 & 0 & 1 & 0.065 & 0.247 \\
\hline 1 if Hispanic & 2,136 & 0 & 1 & 0.073 & 0.260 \\
\hline 1 if less than high school & 2,136 & 0 & 1 & 0.114 & 0.318 \\
\hline 1 if high school & 2,136 & 0 & 1 & 0.333 & 0.472 \\
\hline 1 if some college & 2,136 & 0 & 1 & 0.295 & 0.456 \\
\hline Logarithm of household income $(\$ 1,000)$ & 2,136 & 0.916 & 5.234 & 3.616 & 0.888 \\
\hline Household income $\$ 175 \mathrm{~K}+$ : Yes $=1$ & 2,136 & 0 & 1 & 0.016 & 0.125 \\
\hline Dual income household: Yes $=1$ & 2,136 & 0 & 1 & 0.531 & 0.499 \\
\hline \multicolumn{6}{|l|}{ Housing and location } \\
\hline 1 if single-family house & 2,136 & 0 & 1 & 0.728 & 0.445 \\
\hline 1 if rural area & 2,136 & 0 & 1 & 0.313 & 0.464 \\
\hline $\begin{array}{l}\text { Distance to nearest drop-off col. center }<=5 \mathrm{mi} \\
(\mathrm{Yes}=1)\end{array}$ & 2,136 & 0 & 1 & 0.129 & 0.335 \\
\hline \multicolumn{6}{|l|}{ Attitudes, beliefs, and norms } \\
\hline Perceived obstacles to recycling factor: $1=$ low & 2,107 & 0 & 1 & 0.557 & 0.225 \\
\hline Perceived benefits of recycling factor: $1=$ high & 2,115 & 0 & 1 & 0.773 & 0.172 \\
\hline $\begin{array}{l}\text { Don't blame households like mine for excess } \\
\text { trash: agree }=1\end{array}$ & 2,125 & 0 & 1 & 0.352 & 0.478 \\
\hline $\begin{array}{l}\text { My responsibility is to my family \& myself: } \\
\text { agree=1 }\end{array}$ & 2,127 & 0 & 1 & 0.252 & 0.434 \\
\hline I feel a moral obligation to recycle: agree $=1$ & 2,125 & 0 & 1 & 0.701 & 0.458 \\
\hline \multicolumn{6}{|l|}{ Recycling policies } \\
\hline 1 if state has a bottle bill, 0 otherwise & 2,136 & 0 & 1 & 0.251 & 0.434 \\
\hline $\begin{array}{l}\text { Is curbside recycling available in your } \\
\text { neighborhood (Yes=1)?” }\end{array}$ & 2,136 & 0 & 1 & 0.510 & 0.500 \\
\hline $\begin{array}{l}\text { Is curbside recycling mandatory in your } \\
\text { neighborhood }(1=\text { Yes }) ?\end{array}$ & 2,136 & 0 & 1 & 0.143 & 0.350 \\
\hline $\begin{array}{l}\text { Distance to nearest drop-off collection center for } \\
\text { Aluminum }<=5 \mathrm{mi}(\text { Yes }=1)\end{array}$ & 2,136 & 0 & 1 & 0.230 & 0.421 \\
\hline
\end{tabular}

Notes: $\mathrm{N}$ is the number of observations with valid data. The total number of respondents was 2,136. "s.d." means standard deviation. 